ドーピング検査における国際標準化の最近の動向

\author{
植木眞琴 \\ 三菱化学ビーシーエル ドーピング検査室 \\ 厂174-8555 板橋区志村3-30-1
}

\title{
Recent Movement of International Standardization in Doping Analysis
}

\author{
Makoto UEKI \\ Doping Control Laboratory, Mitsubishi Bio-Clinical Laboratories, Inc. \\ 3-30-1 Shimura, Itabashi-ku, Tokyo 174-8555, Japan
}

(Received 16 April 2004; accepted 6 May 2004)

As court challenges associated with doping in sports increase, implementation of an international standard for the official testing laboratories become an integral part of their quality system. The most common international standard for calibrating laboratories is ISO17025. In many countries, ISO17025 is adapted also for forensic and police laboratories. This paper describes the recent movement of international harmonization of doping analysis in sports.

Key words: ISO17025, Laboratory standard, Measurement uncertainty, Doping control

\begin{abstract}
スポーッ界では, 多国間の有力選手の移籍や，プ ロ・アマオープン化にともなう選手へのインセンテ ィブの増大とドーピング行為に対する罰則の強化に 伴って，陽性判定を受けた選手による上訴事例が増 加して抢り，鑑定を実施する公認検查機関が遵守す べき要求事項の調和が計られている.ドーピング検 查の公認は国際オリンピック委員会医事委員会によ って開始され，当初は要求される検出可能な薬物の 種類や感度などの鑑定技術と一般的な人事・設備を 審査することにもよって行われた，鑑定には高度に 専門的な科学技術が要求されるため, その後上訴過 程に抢ける鑑定結果の受け入れ易さを高める必要性 から，2000年以降ドーピング検査機関には，独立第
\end{abstract}

三者機関から国際基準への適合性審査を受けて認定 を取得し，その信頼性を立証することが求められる ようになってきている.

アメリカでは, 米連邦職域薬物検査規則で定める 尿薬物検查実施機関に適用される国立薬物乱用研究 所 : National Institute on Drug Abuse (NIDA) の試 験所認定プログラム ${ }^{11}$, アメリカ臨床病理医協会 : College of American Pathologists (CAP) の Forensic Urine Drug Testing プログラム ${ }^{2}$ があり, また死 後の化学分析や業務上の運行 · 安全管理能力審査に 関わる薬毒物検査を実施する試験所に関しては，米 法中毒協会/法中毒会議（SOFT/ABFT）による認 定プログラム3)が存在する.これらはいずれも薬毒 物鑑定に特化した専門能力審査認定プログラムであ 
る.

一方，欧州共同体（EU）の統合経済移行に伴っ て，EU 加盟国内試験所間での技術レベルの差異を 埋めるため, 国際計量基準ともいえる ISO17025 規 格4) が幅広く分析化学の分野にも普及するようにな った. ISO17025では, 試験所が実施する校正が国 際計量標準にトレーサブルであり, 提供される分析 サービスが国際基準に基づいて開発・維持・管理さ れ, 実施されていることを審査認定するため, 認定 試験所が発行した公式の試験成績書は，認定を与え た審査機関の相互承認契約 : Mutual Recognition Agreement（MRA）の範囲に基づいて，相手国に自 動的に受け入れられる.

IOC 自身もスポーツ大会を主催する国際競技統 括団体であり, 中立の立場ではあり得ないため, 現 在ではドーピング検査機関の認定業務は IOC 医事 委員会から切り離され，新たに各国政府機関とオリ ンピック関係者とで構成される世界アンチドーピン グ機構 : World Anti-Doping Agency（WADA）に引 き渡された. 現在ではWADA がスポーツ選手, 競 技連盟, 検査機関のいずれからも中立な独立国際機 関としてドーピング問題全般を取り扱っており, ドーピング検査機関の審査・認定も担当してい る5). 現在世界で33の公認ドーピング検査機関が登 録されているが，公式にドーピング検査を実施しよ うとする試験所は, まず ISO 審査機関の監査を受 けて ISO17025 に対する適合性認定を取得し, かつ WADA やその他の組織が提供する技能習熟度試 験：Proficiency Testing (PT) プログラムに一定期 間参加し，そこで所定の成績を修めてからでなけれ ば WADAのドーピング検査機関認定の審査を受け ることができない.

ここでは，ドーピング検査における国際標準化の 最新の動向について解説し, どのように公認検査機 関の能力維持が図られ信頼性が立証されているかに ついて解説する.

\section{適用規格}

ISO規格は認証または認定を受けた事業所の提供 するサービスを利用する側に立った顧客指向の規格 で，しばしば製造業の品質管理が適正に行われてい
ることの証として引用されるため, 一見裁判化学や 法医学とは無縁にみえるが，裁判所をサービス利用 者，鑑定人をサービス提供者と考えれば，ISO 規格 を鑑定所・薬毒物試験所への適用標準としてとらえ ることができる6)．実際，世界でもっとも長い試験 所認定の歴史を持つオーストラリアでは, ISO17025 を法科学鑑定所に適用される技術規格と 位置づけて，政府の委託を受けた独立審査機関であ る豪州試験所認定協会 : National Association of Testing Authority（NATA）が鑑定所の適合性審査 を行って抢り，指紋同定，火災·犯罪現場検証，薬 毒物分析, DNA 解析などの裁判化学分野で多数の 警察機関が認定を受け，登録されている.

製造業の多くが，製品が適正な品質管理の基に製 造されていることを立証するために取得するISO 規格にISO9001 がある。この規格は, 事業所があ らかじめ定められた品質管理基準に従って, 検証可 能な手順でサービスを提供していることを独立審査 機関が審査するプログラムではあるが，かならずし もサービスそのものが最高の品質であることを保証 するものではなく，提供者自身が設定した品質基準 に従ってサービスが供給されていることを立証する 手段の一つとして用いられている。つまり自動車製 造を例に挙げれば ISO9001の“認証 (certify)”は, 全車種に共通な安全基準と, 大衆車は大衆車なりに また高級車は高級車なりに車のグレードに応じた走 行性能・居住性などの付加価值基準とからなる検証 可能な品質目標に従って製品が製造されていること が，独立第三者によって確認されていることを示 す。

一方 ISO17025 は, 校正を伴う計測全般に適用さ れる技術規格であり，独立第三者審査機関によって この規格に適合していると判断され “認定（accreditation)”された事業所の行う校正は，それぞ れの校正の国際規格に対して，一定の不確かさの範 囲でトレーサブルであることが保証される。従っ て，対象事業所には，そこで実施される校正が，と ぎれのない文書による連鎖で国際計量標準に対して 継続性を有することを立証可能であることが要求さ れる，たとえば，ISO17025 認定を受けた質量校正 事業所が発行する質量校正証明書は最終的にキログ 
ラム原器に対する器差とその不確かさが明確である ことを意味し，それらが記載された校正証明書は， 事業所を認定した審査機関が海外の ISO 審査機関 との間で結ぶ MRAの範囲に従って，海外でも自動 的に受け入れられる。事実，NATAによって認定 を受けた試験所が校正し証明書を添えて販売する標 準分銅は，NATA が MRAを結ぶ28力国で自動的 に通用することが保証されている。認定試験所の発 行する校正結果は単なる試験報告書ではなく，校正 証明書としての付加価值が追加されるため, 適合性 を裏書きする表現として ISO90001の“認証”に対 して，SO17025では一段階高い“認定”という用 語が用いられ，その校正証明書には，審查を担当し た審査機関のロゴの使用が許される，サービスを利 用する側は，そのロゴによって相互承認の対象とな る試験成績であるか否かを区別することができる.

大規模国際競技会は数多くのボランティアの協力 を得て開催されるが，ドーピング検査でもあらかじ め所定のトレーニングを受けた開催地の医療スタッ フがボランティアとして動員される. 近年のドーピ ング裁判事例では科学的証拠を覆すことが次第に困 難になってきたため，上訴審ではしばしば試験所業 務外の検査実施の正当性, 検体採取手続きの信憑 性, 守秘義務, 違反の成立可否（競技能力が向上し たか否か）などについて争われることが多くなり， ドーピング検査の実施要領を明確に文書化し，手順 が正しく実施されたことを立証できるようにしてお く必要性が高まってきた。そこで1999年には ISO9001をもとに，検査手続き全般に適用可能な ドーピング検査に関する国際規格：International Standard for Doping Control (ISDC)/ISO PAS18873 が批准された. ISO PAS18873 は検査の 立案, 検查対象競技者への通知, 検体採取セッショ ンの準備と実施, セキュリティ/検査後の管理, 検 体の移送と文書作成など，分析を担当する試験所の 業務以外の手続き全般について規定されている. ISDC の適用対象となるサービス提供者はアンチ ドーピング統括機関，総合国際スポーツ競技会の ドーピング検査実行委員会組織，スポーツ競技連盟 のドーピング検査担当部門などであり，それらの機 関はISO PAS18873に基づいてドーピング検査を
管理運営することが求められる. 世界アンチドーピ ング機構は，ISDCをより実用的な表現に表した 「検査実施の国際基準 : International Standard for Testing Version 3.0」としてホームページ等で広く 一般に公開している5).

試験全体の運営管理を対象とする ISO PAS18873 に対して, 試験所の能力を技術的側面から規定した 規格が「試験所 ·校正機関の能力に関する一般要求 事項：ISO17025」4)である.すでに述べたように， ISO17025（電気工業界では IEC17025 と呼ぶ）は, 校正を実施するすべての試験所に適用可能な一般的 規格として記述されているが，この規格はISO9001 の上位規格であり，ISO9001 に規定されたすべての 品質管理要求を包含し, 校正を行う際の技術的要求 を骨格としている．その技術要求のもっとも重要な 要素に国際的トレーサビリティーの立証, 校正の不 確かさの推計, 調達品の管理, 不測の事態に対する 対処と是正措置などが含まれる，例として化学分析 試験所においては最低限の要求として, 試験所で実 施される温度, 容量, 質量 (重量) 測定などの基本 的計量単位のすべてと, 精度に影響を及ぼすその他 の計量標準類が，国際標準にトレーサブルであり, それら測定単位の不確かさ（Uncertainty）が推計 可能であることが求められている。筆者は, ISO17025を公認ドーピング検査所に適用可能な 「ドーピング検査機関のための国際標準」に置き換 えるための WADA 規格草案策定委員会のメンバー として作業に携わったが，1990年代後半当時, 日本 国内の ISO 審査機関と, 対応する関連国際団体で ある Asia Pacific Laboratory Accreditation Cooperation (APLAC) や International Laboratory Accreditation Cooperation (ILAC) との間には相互監 査に基づいた MRA が成立しておらず，また日本工 業規格の計量基準検定書の多くは不確かさを記載し ていなかったため，仮に日本の計量標準が信頼性の 高いものであったとしても，それらの国内計量標準 を用いて校正された試験結果は, 海外では MRAの 前提条件として受け入れられないのが実状であっ た. その一因として, 計量法改正という障壁や, 我 が国では民間の ISO 審査認定機関に計量標準の校 正やその信頼性を審査認定する権限が与えられてい 
ないという制度上の問題があったのである. そのた め, 薬毒物の検査・鑑定を審査対象として ISO17025の国際認定を取得し, 規格への適合性を 立証するためには, 海外の ISO17025 認定試験所で 校正された計量標準を購入して自機関で校正を行 い，海外の審査機関を招いて審査を受ける必要があ った。

精度を現す要素として，これまで正確度（絶対值 の真值からの隔たり）と精密度（識別可能な最小単 位）という用語がしばしば用いられてきたが，特に 英語に抢いて Precision とAccuracy という用語は しばしば混同して用いられるため, ISOでは「ト レーサビリティー」と「不確かさ」という, より実 用的な用語で校正の信頼性を再定義している.

\section{1 トレーサビリティー}

薬毒物鑑定の精度に影響を及ぼす基本的校正とし て, 天秤の校正とそれに続く標準試料や試薬の科 量, ピペット・フラスコなどの容量精度, GC· $\mathrm{GC} / \mathrm{MS}$ ・反応装置など温度依存機器の校正などが あり, それらの信頼性は指定された適切な頻度で使 用時, または定期的に ISO 対応の検定済み参照標 準品 Certified Reference Material (CRM) に対して 校正される.その結果は, 検証可能な状態で記録 · 保管されていなければならない。 また，より専門的 な校正には質量分析計の質量校正, 尿比重や $\mathrm{pH}$ 測 定のための校正などがある。筆者の研究室の ISO17025 認定範囲は同位体比測定を網羅している が，元素の同位体比測定結果は便宜上, 各元素の国 際標準に対する同位体強度のずれをもって現すこと とされており, 認定要件として質量分析計が同位対 比のCRM に対して正しく校正されていることが必 要とされる. 現在日本国内で入手可能な標準炭酸ガ スは ISO17025 認定試験所で校正されたものではな く, 国際的には受け入れられないので, 我々は米国 NBS (National Bureau of Standard) の提供する国 際二次標準（国際標準の PeeDeeBelemnite: PDB か ら数えて二番目にあたる炭素同位体比国際標準)

NBS-19 Limestone を酸処理して得た同位体比既知 の炭酸ガスを用いて市販の高純度炭酸ガスの炭素同 位体比を校正し, 実試料の測定時に際してはこうし て值付けされた標準炭酸ガスで使用の都度 MS 装
置を校正している. その結果得られた同位体比の精 度は抢よそ0.3\%（千分の0.3）以内の誤差に収まる と言われて抢り, 未知試料の測定結果から炭素原子 の由来を推計するにあたり，信頼し得る海外の専門 誌に報告された炭素同位体比データベースとの絶対 值での比較を可能としている.

\section{2 測定の不確かさ}

一般に測定值の信頼性を表す単位として標準偏差 が用いられるが，ISO17025では，自機関開発試験 法については不確かさを推計するよう求めている. 不確かさとは, 分析值にふくまれる補正できないバ イアス要因であり, その值は真の值が存在する範囲 を示すものと定義される，標準偏差をもちいる測定 值の信頼域表現では, 測定值を正規分布と仮定し, 全行程を一括した場合の分布範囲を示しており，個 別の䛊差要因については配慮されていないのに対し て, 不確かさの推計では, 個々の誤差要因について 求めた標準偏差（標準不確かさ）から，それぞれの 変動係数 (相対標準不確かさ Ui : 標準不確さ/対象 の質量, 容量など）を求め, それらの自乗を合算し た值の平方根を，測定系全体の不確かさを意味する 合成標準不確かさと定義して用いている。

\section{合成標準不確かさ $: \mathrm{Uc}=\sqrt{\left(\Sigma \mathrm{Ui}^{2}\right)}$}

測定結果の報告に際して不確かさを用いてその信 頼域を表現する場合，必要とされる信頼水準 （Confidence level：基準正規分布の面積）に対応し た包含係数 (Capacity factor: k) の值, たとえば 要求される信頼水準が $95.44 \%$ また $99.74 \%$ の時, $\mathrm{k}=2$ または 3 を乗じた值（拡張不確かさ）が評価 の対象となる.

拡張不確かさ: $\mathrm{U}=\mathrm{Uc} \times \mathrm{k}$

ドーピング検査結果の報告では $\mathrm{k}=2$ の時の拡張 不確かさ表現が用いられている. 日常的な化学分析 の多くに抢いてU 值の有効数字は 1 ないし 2 桁 で, 端数は常に切り上げられる.

日本で実施されている薬毒物検査では必ずしもカ ットオフ (許容上限) 值の概念が定着していないが, 米国職域薬物検査規則やドーピング検査ではいくつ かの薬物についてカットオフ值が設定されている. カットオフ值を適用することにより，大麻のように 喫煙で乱用される規制物質への低濃度間接暴露によ 
る偽陽性を排除でき，あるいは同一の被疑者につい ての判定がある試験所で陽性，ほかの試験所で陰性 と異なる判定を下される危険性を排除でき，より客 観的な判定が可能となる．このように許容值によっ て規制される薬毒物の分析における不確かさ表現の 意味を以下のように解釈することができる.

検査がスクリーニングと確認分析の二段階で実施 される場合，スクリーニングの不確かさが明らかで あれば，スクリーニングの平均值がカットオフ值周 辺である場合に，偽陽性（偽陰性）を排除するため の確認分析が必要であるか否かをより客観的に判断 できる。また，確認検査で Fig. 1 中 a 抢よび d の 場合，分析結果はそれぞれ明らかに陽性，陰性と判 断されるが，規制值が不確かさを許容しない場合に は， c はカットオフ值との有意差がないため陰性と 判定される. b の場合, 平均濃度は許容值上限を越 えているが，許容值上限が不確かさの範囲に含まれ るため，一般に定性検査では陰性と判定される。 た定量検査の場合には，定量值の平均值がカットオ フ值以上であるが，カットオフ值濃度が測定の不確 かさの範囲に入ることを報告し，陽性・陰性の判定 は検査依頼者に委衫られる。不確かさの詳細に関す る文書は Eurachem (Analytical Chemistry in Europe）のホームページ7)で提供されており，質量分 析に関する解説8) もあるので参照願いたい.

\section{3 技能習熟度試験（PT: Proficiency Testing）}

試験所の能力を検証するために，素性の明らかな 試料を配布してその測定值を試験所間で比較する様 々な PT プログラムが提供されている．このような
比較試験を Ring Test と呼ぶ場合もある．特にアメ リカ・オーストラリアでは麻薬・覚醒剂などの規制 薬物を対象とした PT が頻繁に実施され，しばしば カットオフ值付近の大麻代謝物の定量精度評価や, 検出は容易であるが確認試験が困難なメサドンなど のような規制薬物の鑑定能力の評価を目的とした試 料が配布される. ISO17025 やCAP の認定審査で は, 外部精度管理プログラムへの参加記録と評価結 果は認定審査の対象となり, 查察を通じて試験所の 技能研修プログラムが組織内で日頃有効に機能し， 定期的に技能の見直しがはかられ，必要な是正措置 がとられているかどうかが調べられる。また， CAP な゙の有償のPT プログラムでは, 参加希望 者に分野ごとの試験検体が定期的に配布され，後日 参加機関全体の集計結果と自機関の評価結果が添え られたレポートが送付されてくる. 薬毒物・裁判化 学領域では, 業務の特殊性故にしばしば啇用可能な PT プログラムが無い場合が想定されるが， ISO17025ではこのような場合に類似の分析を行う 試験所間で共通の試料を融通し合い，自主的に精度 を比較するよう推奨している.

一方 WADA が実施するドーピング検査機関の $\mathrm{PT}$ は以下のように 3 階層に分けて, 最低年 4 回実 施されている.

Open PT：テスト検体であることが明らかで目 標值も知らされている教育的試験

Open-Blind PT : テスト検体であることは知らさ れるが目標值が伏せられている 能力評価試験
a. Mean \pm expanded uncertainty $>$ Threshold
b. Mean
$>$ Threshold
Mean - expanded uncertainty $<$ Threshold
c. Mean
$<$ Threshold
Mean + expanded uncertainty $>$ Threshold
d. Mean \pm expanded uncertainty $<$ Threshold

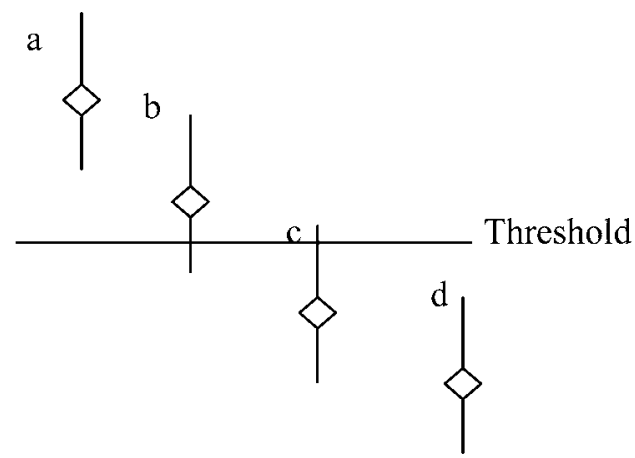

Fig. 1 Interpretation of measurement uncertainty for threshold substance 
Double Blind PT : 日常の実検体の検査として依 頼され，目標值の事前通知も ない試験

Open PT は新たに追加された検査項目の性能評 価などの目的で実施され, 各試験所は Open PT 検 体を利用して新しい検査方法の能力を検証すること が推奖される。 また Open-Blind PT は，試験所間 の差異が生じやすい定性試験, カットオフ值が設定 されている定量試験などにおいて, 分析結果を比較 し，より高い精度を実現するために実施される。

Double Blind PT は, 試験所の平常時の処理能力お よび技能が常に有効に発揮されていることを検証す る目的で実施され, 特に大規模総合国際競技会の期 間中に検体が送付される場合が多い. 長野オリンピ ックなどの総合国際大会の検查では期間中に 3 から 5 検体程度の Double Blind PT 検体が混入されてお り，その評価結果は大会時の検査が適切に実行さ れ, 自国選手の陽性結果隠蔽などの不正操作がなか ったことを示す証拠としても用いられた.

年一回実施される認定試験では Open-Blind PT 試料を用いた技能試験で成功裏に所定の成績を収め る必要がある。ドーピング検査機関認定のための試 験では，偽陰性結果は一時的に認定が保留されたの ち, 必要な是正措置がとられたことが確認されれば
公式な試験の実施に復帰できるが，偽陽性は容認さ れないため, 偽陽性結果を報告した試験所に対して は是正措置が取られた後も引き続き一定期間試験の 実施が制限される。

Fig. 2 は, 複数のドーピング検査機関が自主的に 実施したカフェイン定量のための Open-Blind PT の集計結果を Z-score と呼ばれる数值に置き換え, その結果を図示した例を示している．Fig. 2 は，3 力所の試験所で是正措置が必要なことを示してお り，うち一つの試験所では 2 種類の試験検体分析の 結果が集計值平均 +2 score と +3 score 外と高值であ り，正の系統誤差が不確かさ増大の要因であった. 他の試験所では試料 6A については集計值平均とほ ぼ一致したものの, 試料 6B の結果は集計值平均一 2scoreから-3score 付近で逸脱しており，ばらつき による誤差，あるいは測定精度に試料マトリックス の影響が関与していることが推測されるため，何ら かの是正措置が必要と判断された. Fig. 2 では一般 的なカフェインの例を示したが，試験所が検索対象 とする成分の多くは日頃遭遇する機会の少ない化学 物質であり，計画的に習熟を計っていかなければ十 分な精度を維持できず，緊急時の要求に即時対応で きない事態も危惧される．PT プログラムは試験所 の能力を維持 · 向上させ, 測定結果の受け入れ易さ

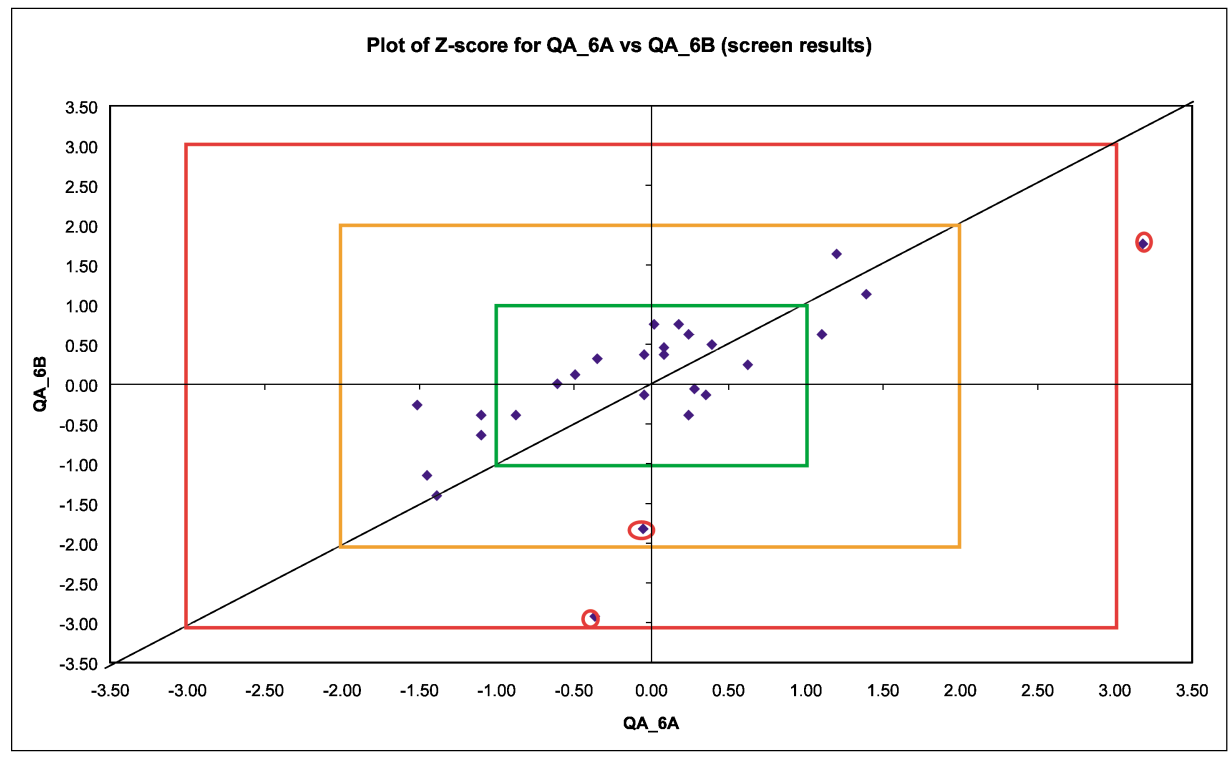

Fig. 2 Z-scores obtained form inter-laboratory proficiency testing on caffeine 
を高めるための重要な手段の一つとして, 国際基準 の普及に伴って，より広範囲に実施されるであろ う.

\section{4 試験の品質に影響を与えるその他の背景}

ISO17025 では, 購買時の外部調達品の品質, 顧 客支給品の管理, 下請け契約, 試験依頼者の要請に 対する協力など，試験の品質に影響を与えるその他 の背景に関しても具体的に要求事項を記述してい る. 試験に用いる器具・試薬類は供給者, 仕様, グ レード，有効期限などを明文化し，不適切な品目が 誤って使用されないような防止策を講じておかなけ ればならない。特に標準試料や測定キットなどのよ うに測定精度に直結する品目は，使用に先立ってそ の品質を確認するよう求礼てる。依頼者から物品 の提供を受けて試験を実施する場合, あらかじめ顧 客支給品の管理方法を定めておくのが望ましい。裁 判化学々同様に，ドーピング検査においても試験所 内での試料の個体識別と生データの一貫性の保証 (Chain-of-Custody) が特に重要であり, 上訴過程 でもそれらの点に問題がなかったかどうかがしばし ば争点になる，提供を受けた被験検体は検査対象物 質そのものであり, 試験が完了するまで適切な環境 下で保管され，試験所内での取り扱いはとぎれのな い文書の連鎖によって記録され検証可能でなければ ならない，何らかの理由で試験の一部または全部を 下請けに出す場合，その依頼先もISO17025の認定 試験所でなければならない。必要な場合，依頼者に はみずからの責任において外部調達品に関する品質 記録を取り寄せ，または下請け先の信頼性を検証す るための監査を行うことが推奨されている.

\section{5 監査}

試験結果によって依頼者が選手の資格剥奪や競技 記録の抹消などの重要な判断をしなければならない 場合，依頼者またはその代理者による依頼業務実施 状況の監視や試験への立ち会いを要請される場合が ある．そのような検証を可能とするため，ドーピン グ検査では被験者立ち会いの下で被験検体を採取時 に二分割してその各々をユニークなコード番号付き A，B それぞれの容器に封印し，一方は立ち会い検 査に備えて封印したまま一次結果確定まで保管され る.WADAの反ドーピング規則は試験所の守秘対
応を要求する一方で, 試験の信頼性検証の機会を与 えるために, サービスを利用する依頼者（アンチ ドーピング機関，スポーツ競技団体，当該選手）の 施設への立ち入りを容認しており，オリンピックな ぞの大規模総合国際競技会では，検査所に WADA の独立監視員を派遣して検査プロセスを監視するの が慣例となっている.

試験所の監査実施は，ISO17025においてその信 頼性を保証する重要な手法であるが，試験所は，認 定施設と独立かつ一定の権限をもった内部監査員を 養成し, 年二回以上の内部監査を実施しなければな らない。これは本来審査機関の監査員によって実施 されるべき監査を補うため, その権限を内部監査員 に委譲して定期的に適用規格への試験所の適合性を 検証するための手続きであり, 監査結果は監查報告 書として文書化され, 試験所の運営管理権限をもつ 管理者に報告される。必要ならば改善勧告が出され るが，それら一連の記録は認定審査時に外部監査員 によって審査され，必要な是正措置が取られている かが確認される。

\section{6 文書と実験データの管理}

ISO9001/17025 では管理が必要な文書を次の $4 つ$ の階層に分類している.

一次文書 : 品質マニュアル

二次文書 : 規程類 ·規則書

三次文書 : 作業標準類（標準操作手順書, 操作マ

$$
\text { ニュアル) }
$$

四次文書 : 記録類・生データ

品質マニュアルは，試験所の規格適用範囲全般の 品質システムを記述した最高位の文書で，いわば試 験所の憲法として位置づけられており，通常 ISO17025 の項番号に対応して試験所の品質ポリ シーが記述されている．組織内で遵守すべき規程・ 規則は二次文書に分類されるが，二次文書には組織 内の別の部門が発行し試験の品質に影響する文書, たとえば人事部門が発行する職員就業規則, 調達部 門が発行する購買規則なども含まれる.

三次文書は試験の手順や機器の操作 · 保守点検方 法を記述した，いわゆる SOP (Standard Operating Procedure）または Operation Manualで, 認定対 象範囲に含まれるすべての試験について三次文書が 
用意されていなければならない。必要に応じて実験 室にそれらのコピーを配置しても良く, SOPを習 得した試験担当者が実験台で用いるための簡易操作 フローなども含まれる. 事前の準備が困難で, 発生 の都度実施される非証明分析法については，その試 験を実施するための要件, 試験方法の選択と精度の 検証方法, 分析結果の採用基準 - 再検査基準などの 指針が具体的に記述された三次文書が用意される。

試験実施の過程で発生したすべての生データ・作 業日誌類, 結果の控えなどは四次文書に分類され る.

これら文書の管理法は文書管理規定に記述され， 文書管理規定自体は二次文書に分類されるが，一次 文書から三次文書までは改訂の必要が生じた時およ び定期的に見直し，必要があれば担当の責任者によ って改訂され，旧版と厳重に識別される。 また，四 次文書は顧客からの要請や監查に備えて, 不用意に 意図的な変更が加えられ, あるいは情報が漏洩する ことのないよう, 専用の文書保管庫 (archive) に 一定期間施錠保管される. 通常四次文書は陰性結果 の場合には報告後最低 3 年, また係争中の関連デー タについては最低限結審まで引き続き保管される.

\section{試験結果にまつわる国際紛争と ISO の役 割}

ISO17025 適合性認定を受けた試験所が発行する 試験結果は, 審査を担当した機関が海外の審査機関 との間で結ぶ MRAの範囲に基づいて相手国に自動 的に受け入れられることは既に述べた. 認定試験所 によって提供されたサービスに疑義を生じた場合, その国のISO 審査機関を通じて, 試験成績書を発 行した国の審査機関に検証のための調査を依頼する ことが可能であり, 必要ならば担当審査機関は当該 試験所の追加の監査を実施し, あるいは文書で回答 を求めることができ, このような対応が可能な故に 認定試験所には試験結果の国際間での受け入れ易さ が保証されているとも考えられる.

2002年にいくつかのドーピング裁判で学識経験者 として証言した国際標準化機構委員の Adriaan van der Veen は, 在欧の複数の IOC/WADA 認定ドー ピング検査機関が発行した陽性結果報告書において
測定の不確かさが過小に見積もられているため, 少 なくとも 7 人の世界的レベルのスポーツ選手が不当 に陽性判定を受けていると主張した99). 反ドーピン グ規則には19-ノルテストステロンおよび大麻代謝 物（THC カルボン酸体）のカットオフ值はそれぞ れ $2 \mathrm{ng} / \mathrm{ml}$ および $15 \mathrm{ng} / \mathrm{ml}$ と設定されているが， van der Veenによれば，測定の不確かさを考慮す ると処罰可能な最小濃度 (Sanction Limit) はそれ ぞれ抢よそ $17 \mathrm{ng} / \mathrm{ml}$ と $57 \mathrm{ng} / \mathrm{ml}$ であり, 上記 7 人 の選手の検査結果は彼が試算した Sanction Limit 以下であったと報告された。そこでIOC/WADA 認定検査機関責任者で構成される World Association of Anti Doping Scientists (WAADS) では, WAADS が定期的に実施しているPT の集計結果か ら, IOC/WADA 認定検査機関間の測定の不確かさ を慎重に算出した結果, 不確かさを考慮した陽性判 定の判定限界（Decision Limit）はそれぞれ3.3 ng/ $\mathrm{ml}$ と $22 \mathrm{ng} / \mathrm{ml}$ であり, 先の 7 例に抢ける偽陽性判 定の事実はなかったことが確認された。その結果は 検査を担当した当事者の一人であるべルギー Gent laboratory の Peter Van Enooによって Accred Qual Assur 誌にLetter to the editorとして報告され た ${ }^{10)}$ 。不確かさの解釈に差違が生じた原因はvan der Veen が非 IOC/WADA 認定試験所によって投 稿された精度の低い文献を引用して不確かさを試算 したこと, また計量標準類校正証明書の不確かさは 一般に観測値の上下両端の幅（平均值士不確かさ） で表現されるが，カットオフ值のそれは設定值の上 側（許容值上限＋不確かさ）のみが問題とされるた め, 陽性判定の不確かさの範囲は, 計量標準類の校 正証明書のそれに対して半分になるためであった。

\section{結 語}

試験結果の影響が多国間に及ぶドーピング検査で は, 試験所の信頼性を客観的に立証する必要性か ら, 国際規格への適合性審査・認定制度が導入され るようになった。例示した多国間のドーピング裁判 論争をきっかけに，ドーピング検査における測定の トレーサビリティーの立証・不確かさ推計と国際紛 争に抢ける ISO17025 適合の重要性が改めて認識さ れるようになった。 
外部規格の導入は新たな管理業務の増加につなが るが，結果的に試験所の技能向上と自己防衛の手助 けになり，試験結果の受け入れ易さを向上させるこ とによって業務のより円滑な遂行が可能となる. 我 が国では裁判化学や薬毒物分析分野における試験所 認定制度は十分に普及しているとは言い難いが，そ の一因として各専門分野の審査基準が未整備なこと と, 専門能力を有する審査員養成の遅れがあげられ る. 現時点では，技術要求が明らかで公定法が設定 されているダイオキシン分析を請け負う受託検査機 関を中心に ISO17025 適合性審査・認定が普及しつ つあり，また医療過誤が患者の生命に直結する臨床 検査分野に拈いても，本年から ISO17025 を基にし た ISO15189適合性審査が開始される予定になって いる.

我が国の鑑識科学技術の国際的な認知度をより高 める上でも，鑑識分野の審査基準整備と審査員の早 期養成が望まれる.

\section{文 献}

1) Office of the secretary-DOT: Procedure For Transportation Workplace Drug and Alcohol Testing Programs. Federal Register 67, 79462 (2000).

2) CAP Commission on Laboratory Accreditation: Checklist for Laboratory Accreditation Program on Forensic Urine Drug Testing. http: / / www.cap.org / apps / docs / laboratory _ accreditation / checklists / forensic_urine _ drug _ testing_march2004.doc, (2004, The College of American Pathologists Internet homepage).

3) The Society of Forensic Toxicologists: Inc.and the American Academy of Forensic Sciences.
SOFT/AAFS Forensic Laboratory Guidelines2002.

http: // www.soft-tox.org/Guidelines / default.asp (2004, SOFT Internet Homepage).

4）日本規格協会編：対訳 ISO17025_試験所・校 正機関の能力に関する一般要求事項, 日本規格 協会, 東京 (2003).

5) World Anti Doping Agency: International Standard for Testing Version 3.0 (2004).

http: // www.wada-ama.org / en / t2.asp? $\mathrm{p}=42240$ (2004, WADA Internet Homepage).

6) Aumeer-Donovan S. B.: Quality in Australian Forensic Science. Quality Australia, 17(3), (2003).

http: / / www.nata.asn.au // fs_publications.htm NATA news (2004, NATA Internet Homepage)

7) Eurachem: Guide; Quantifying Uncertainty in Analytical Measurement (2000, Eurachem). http: / / www.eurachem.ul.pt / guides / QUAM2000-1.pdf (2004, Eurachem Internet Homepage)

8）植木眞琴 : 薬毒物検査, 鑑識分野における質 量分析法.，ぶんせき. 11，630-635（2003）。

9) Van der Veen A. M. H.: Measurement uncertainty and doping in sports, Accred Qual Assur 8, 334-339 (2003).

10) Van Eenoo P. and Delbeke. F. T.: Reply to "Measurement uncertainty and doping control in sport" by A. van der Veen, Accred Qual Assur (2003) 8: 334-339, Accred Qual Assur, 8, 477-479 (2003). 